\title{
Behavioral Sensitization to Cocaine Is Associated with Increased AMPA Receptor Surface Expression in the Nucleus Accumbens
}

\author{
Amy C. Boudreau and Marina E. Wolf \\ Department of Neuroscience, The Chicago Medical School at Rosalind Franklin University of Medicine and Science, North Chicago, Illinois 60064-3095
}

\begin{abstract}
Regulation of AMPA receptor trafficking is important for many forms of neuronal plasticity. In this study, a protein cross-linking assay was used to evaluate the contribution of AMPA receptor trafficking to plasticity associated with behavioral sensitization, an animal model of drug addiction. Cross-linking was used to distinguish between cell surface and intracellular AMPA receptors in nucleus accumbens $(\mathrm{NAc})$ tissue obtained from rats treated repeatedly with saline or cocaine. Surface/intracellular (S/I) ratios for glutamate receptor 1 (GluR1) and GluR2/3 subunits were increased $21 \mathrm{~d}$ after the last injection in cocaine-sensitized rats but not rats that failed to sensitize, and the magnitude of the $S / I$ ratio for cocaine-sensitized rats was positively correlated with the magnitude of behavioral sensitization. At the $1 \mathrm{~d}$ withdrawal time, cocaine did not alter S/I ratios, and there was no correlation between S/I ratios and behavioral sensitization. The majority of surface-expressed GluR1 detected with this assay was associated with synapses, based on coimmunoprecipitation with postsynaptic density protein of $95 \mathrm{kDa}$. These findings suggest that behavioral sensitization to cocaine is associated with a slowly developing redistribution of AMPA receptors to the surface of NAc neurons. Motor execution of drug-seeking responses depends on activation of AMPA receptors on NAc neurons by glutamate afferents originating in cortical and limbic regions. We propose that drug-seeking responses are more effectively triggered in cocaine-sensitized rats because of increased cell surface expression of AMPA receptors.
\end{abstract}

Key words: addiction; AMPA receptor; cocaine; nucleus accumbens; rat; sensitization; trafficking; ventral tegmental area

\section{Introduction}

Trafficking of AMPA-type glutamate receptors (AMPARs) into and out of synapses is an important mechanism for regulating synaptic strength in several types of activity-dependent plasticity, including long-term potentiation (LTP), long-term depression (LTD), and synaptic scaling (Malinow and Malenka, 2002; Bredt and Nicoll, 2003; Turrigiano and Nelson, 2004). The goal of this study was to determine whether AMPAR trafficking contributes to neuroplasticity associated with behavioral sensitization, an animal model of drug addiction. Sensitization refers to the augmentation of behavioral responses to drugs of abuse that occurs during their repeated administration and persists long after drug exposure is discontinued. Sensitization of locomotor stimulatory effects is commonly studied, but more importantly, sensitization develops to the incentive-motivational properties of drugs, that is, properties that make them "wanted" (Robinson and Berridge, 2000). (M.E.W.). A.C.B. was supported by predoctoral National Research Service Award DA019762. We thank Drs. Michael Browning and Jose Esteban for helping with development of the $B S^{3}$ cross-linking protocol used in our experiments.

Correspondence should be addressed to Marina E. Wolf, Department of Neuroscience, The Chicago Medical School at Rosalind Franklin University of Medicine and Science, 3333 Green Bay Road, North Chicago, IL 60064-3095.
We focused on the nucleus accumbens (NAc) because it serves as an interface between corticolimbic regions important for motivation and motor regions important for behavioral output and thus plays a key role in generating motivated behaviors related to natural rewards as well as drugs of abuse (Kelley, 2004). Glutamate transmission in the NAc, mediated by AMPARs, is necessary for behavioral adaptations resulting from previous cocaine exposure. For example, expression of behavioral sensitization to cocaine is blocked by intra-NAc injection of an AMPAR antagonist, and sensitized rats have an increased locomotor response to intra-NAc injection of AMPA (Pierce et al., 1996). This heightened response to AMPA may represent a link between sensitization and reinstatement models, because AMPAR transmission in the NAc is required for reinstatement of drug seeking after extinction (Cornish and Kalivas, 2000), and a priming injection of AMPA into the NAc is more effective at reinstating cocaine seeking in rats tested several weeks after exposure to psychomotor stimulants (Suto et al., 2004).

These findings could be explained by an increase in cell surface expression of AMPARs in the NAc of cocaine-sensitized rats. We tested this possibility using a membrane-impermeant protein cross-linking reagent, bis(sulfosuccinimidyl)suberate $\left(\mathrm{BS}^{3}\right)$, to distinguish between cell surface (S) and intracellular (I) receptor pools in NAc tissue obtained from cocaine- or saline-treated rats. $\mathrm{BS}^{3}$ cross-linking assays have been used previously to monitor changes in glutamate receptor distribution in dissociated cells 
(Hall and Soderling, 1997a,b; Hall et al., 1997; Archibald et al., 1998) and hippocampal slices (Broutman and Baudry, 2001; Clayton et al., 2002; Grosshans et al., 2002a,b; Gerges et al., 2004). We adapted the assay to detect receptor trafficking produced by in vivo drug treatment in intact rats. Using this approach, we found that cocaine-sensitized rats exhibit an increase in AMPAR surface expression in the NAc that is correlated with the magnitude of behavioral sensitization. These results, the first to directly demonstrate regulation of AMPAR trafficking by in vivo treatment with drugs of abuse, provide a mechanism that may account for enhancement of addiction-related behaviors in cocainesensitized rats (Pierce et al., 1996; Suto et al., 2004). This modified cross-linking assay can be applied to any animal model of behavioral plasticity and many different receptor proteins.

\section{Materials and Methods}

Animals. Male Sprague Dawley rats weighing 250-275 g (Harlan Laboratories, Indianapolis, IN) were housed in groups of three with food and water available ad libitum. A $12 \mathrm{~h}$ light/dark cycle was used with the lights on at 7:00 A.M. All saline or cocaine injections and behavioral testing were performed between 11:00 A.M. and 4:00 P.M. All procedures were approved by the Institutional Animal Care and Use Committee of Rosalind Franklin University of Medicine and Science.

Repeated cocaine or saline treatment and behavioral analysis. All rats were assigned to saline and cocaine treatment groups after $10 \mathrm{~d}$ of acclimation to the home cage environment and daily handling. Twenty-four hours before the first cocaine or saline injection, animals were habituated to the behavioral testing procedure by placement in photocell cages (one animal per cage; San Diego Instruments, San Diego, CA) for $20 \mathrm{~min}$. They received a mock injection (syringe without needle touched to abdomen) and then remained for $2 \mathrm{~h}$ in the photocell cages. On the first day of treatment (day 1), animals were habituated to photocell cages for 20 min before injection of cocaine $(15 \mathrm{mg} / \mathrm{kg}$, i.p.; donated by the National Institute on Drug Abuse, Bethesda, MD) or saline ( $1 \mathrm{ml} / \mathrm{kg}$, i.p.). Locomotor activity (total beam breaks) was measured for $2 \mathrm{~h}$. For the next $5 \mathrm{~d}$, animals received cocaine $(30 \mathrm{mg} / \mathrm{kg}$, i.p.) or saline ( $1 \mathrm{ml} / \mathrm{kg}$, i.p. $)$ in home cages. On the last day of treatment (day 7), animals returned to photocell cages for $20 \mathrm{~min}$ of habituation, cocaine $(15 \mathrm{mg} / \mathrm{kg}$, i.p.) or saline (1 $\mathrm{ml} / \mathrm{kg}$, i.p.) injections, and $2 \mathrm{~h}$ of locomotor activity measurement. This cocaine regimen (Pierce et al., 1996) was chosen because it produces well characterized adaptations in glutamate transmission in the NAc (Vanderschuren and Kalivas, 2000) and is similar to a protocol we used previously to study changes in glutamate receptor sensitivity in the NAc associated with sensitization (White et al., 1995). Criteria for sensitization were based on the coefficient of variance $(\mathrm{CV})$ of the day $7 /$ day 1 beam-break ratio in the saline group $(\mathrm{CV}=\mathrm{SD} /$ mean $)$. The $\mathrm{CV}$ provides a measure of variability within the saline group. A cocaine-injected rat was considered sensitized if its increase in activity over the course of cocaine treatment (day 7/day 1 beam break ratio) exceeded the $\mathrm{CV}$ of the saline group (e.g., a cocaine rat with day $7 /$ day $1=1.57$ would have a $57 \%$ increase in activity and would just meet criteria for sensitization if the $\mathrm{CV}$ for the saline group was 0.56 ). For this analysis, day $7 /$ day 1 beam break ratios were calculated based on the first $30 \mathrm{~min}$ of activity after injection.

Surface receptor cross-linking with $B S^{3}$. Either 1 or $21 \mathrm{~d}$ after the last daily injection of cocaine or saline, rats were decapitated. Brains were rapidly removed, a $2 \mathrm{~mm}$ coronal section containing the NAc was obtained using a brain matrix, and the NAc was dissected on an ice-cold platform. The dissected pieces of tissue contained both core and shell subregions of the NAc, although there was relatively more core tissue. The need to dissect rapidly while completely excluding non-NAc tissue led us to emphasize the core, because landmarks in fresh tissue for defining the dorsal and lateral borders of the NAc are more clear-cut than those for defining medial and ventral borders. Bilateral pieces of NAc tissue from each rat were then chopped into $400 \mu \mathrm{m}$ slices using a McIllwain tissue chopper (The Vibratome Company, O'Fallon, MO). Slices were added to eppendorf tubes containing ice-cold artificial CSF spiked with $2 \mathrm{~mm} \mathrm{BS}^{3}$ (Pierce, Rockford, IL). Incubation with gentle agitation proceeded for $30 \mathrm{~min}$ at $4^{\circ} \mathrm{C}$. Cross-linking was terminated by quenching the reaction with $100 \mathrm{~mm}$ glycine $\left(10 \mathrm{~min}, 4^{\circ} \mathrm{C}\right)$. The slices were pelleted by brief centrifugation, and the supernatant was discarded. Pellets were resuspended in ice-cold lysis buffer containing protease and phosphatase inhibitors [25 mм HEPES, pH 7.4, $500 \mathrm{~mm} \mathrm{NaCl}, 2$ mм EDTA, $1 \mathrm{~mm}$ DTT, $1 \mathrm{~mm}$ phenylmethyl sulfonyl fluoride, $20 \mathrm{~mm} \mathrm{NaF}, 1 \mathrm{~mm}$ sodium orthovanadate, $10 \mathrm{~mm}$ sodium pyrophosphate, $1 \mu \mathrm{M}$ microcystin-LF, 1 $\mu \mathrm{M}$ okadaic acid, $1 \times$ protease inhibitor mixture (Calbiochem, La Jolla, $\mathrm{CA})$, and $0.1 \%$ Nonidet P-40 (v/v)] and homogenized rapidly by sonicating for $5 \mathrm{~s}$. Total protein concentration of lysates was determined by the Lowry method (Lowry et al., 1951). Samples were aliquoted $(\sim 15$ aliquots per rat) and stored at $-80^{\circ} \mathrm{C}$ for future analysis. Samples from the ventral tegmental area (VTA) were processed similarly, except that it was not necessary to chop the small piece of dissected VTA tissue before cross-linking. Alternative methods exist for monitoring receptor surface expression (e.g., chymotrypsin digestion and biotinylation). In dissociated cultures, these methods and the $\mathrm{BS}^{3}$ assay yield nearly identical estimates of the percentage of total glutamate receptors on the cell surface (Hall and Soderling, 1997a,b; Hall et al., 1997). The chymotrypsin method was not selected, because the chymotrypsin incubation occurs at $37^{\circ} \mathrm{C}$, raising concerns about receptor redistribution, and because changes in surface-expressed receptors are inferred from quantification of the internal (intact) receptor, which is problematic if total receptor expression is changed by the experimental treatment, as can occur after repeated exposure to psychomotor stimulants (Wolf, 2003). The biotinylation method can be used in brain slices (Gutlerner et al., 2002; Heynen et al., 2003). However, biotin-treated samples must be purified into biotinylated (S) and nonbiotinylated (I) fractions before analysis. Then, biotinylated and nonbiotinylated fractions must be measured in separate SDS-PAGE lanes and normalized to total protein for comparison. Potential error is introduced at purification and normalization steps. In contrast, $\mathrm{BS}^{3}$ samples can be analyzed directly by SDS-PAGE without purification, and $\mathrm{S}$ and I bands are measured in the same lane, avoiding the need for normalization and increasing sample through-put.

Western blotting. Samples (20-30 $\mu$ g total protein/lysate) were loaded and electrophoresed on a $4-15 \%$ gradient Tris- $\mathrm{HCl}$ gel (Bio-Rad, Hercules, CA) under reducing conditions, and proteins were transferred onto polyvinylidene fluoride (PVDF) membranes for immunoblotting. Membranes were washed in double-distilled $\mathrm{H}_{2} \mathrm{O}\left(\mathrm{ddH}_{2} \mathrm{O}\right)$ and blocked with $1 \%$ goat serum $/ 5 \%$ nonfat dry milk in TBS-Tween 20 (TBS-T), pH 7.4 , for $1 \mathrm{~h}$ at room temperature (RT). Membranes were then incubated with antibodies to AMPAR subunits [glutamate receptor 1 (GluR1), 1:500; GluR2/3, 1:2000; Chemicon, Temecula, CA] overnight at $4^{\circ} \mathrm{C}$. Membranes were washed extensively with TBS-T solution, incubated for 60 min with HRP-conjugated anti-rabbit IgG (1:10,000; Upstate Cell Signaling, Lake Placid, NY), and washed extensively again in TBS-T. Membranes were then rinsed with $\mathrm{ddH}_{2} \mathrm{O}$, immersed in chemiluminescence (ECL) detecting substrate (Amersham Biosciences, Piscataway, $\mathrm{NJ}$ ) for $3 \mathrm{~min}$, and exposed to HyperFilm ECL film. The diffuse densities of surface and intracellular bands in each lane were determined using TotalLab (Nonlinear Dynamics, Newcastle, UK). When needed, total protein in each lane was determined by staining membranes with Ponceau S (Sigma-Aldrich, St. Louis, MO).

Coimmunoprecipitation. Total protein $(100 \mu \mathrm{g})$ from a cross-linked NAc membrane preparation [prepared as described by Hunter et al. (1990)] was dialyzed against $100 \mathrm{~mm}$ Tris- $\mathrm{HCl}, \mathrm{pH}$ 7.5, 0.1\% (v/v) Triton $\mathrm{X}-100$, and $10 \%(\mathrm{v} / \mathrm{v})$ glycerol overnight at $4^{\circ} \mathrm{C}$. After centrifugation for $1 \mathrm{~h}$ at $100,000 \times \mathrm{g}$, the sample was preincubated with either $2 \mu \mathrm{g}$ of anti-postsynaptic density protein of $95 \mathrm{kDa}$ (PSD-95) antibody (Upstate Cell Signaling) or $2 \mu \mathrm{g}$ of anti-mouse IgG control antibody (Santa Cruz Biotechnology, Santa Cruz, CA) for $4 \mathrm{~h}$ at $4^{\circ} \mathrm{C}$ before the addition of $5 \mu \mathrm{g}$ of protein $\mathrm{A} / \mathrm{G}$-agarose beads (Santa Cruz Biotechnology). After mixing at $4^{\circ} \mathrm{C}$ overnight, the sample was centrifuged and the supernatant ("unbound fraction") was collected and mixed with reducing sample treatment buffer ( $\mathrm{rSTB})$. The beads were then washed three times in ice-cold TBS-Triton X-100 [0.1\% (v/v)], pH 7.4, and resuspended in an adjusted volume of rSTB to generate a "bound fraction" of equal volume and dilution as the unbound fraction. Fractions were then boiled, separated by $4-15 \%$ gradient SDS-PAGE, and transblotted to PVDF membranes 
for immunodetection of GluR1. The percentage of coimmunoprecipitation was determined by applying the following formula to the immunodetected surface band: [bound/(bound + unbound) $\times 100$.

Data analysis. Two-way ANOVA with time as the repeated measure was used to compare locomotor activity counts on days 1 and 7 of behavioral trials. Individual time points were compared between days using a post hoc Tukey's test. For Western blots, measurements of the S/I ratio and $(\mathrm{S}+\mathrm{I})$ /total protein per lane in cocaine-injected rats were normalized to saline control values. Differences between groups were determined using ANOVA followed by a post hoc Tukey's test. Significance was set at $p<0.05$.

\section{Results \\ $\mathrm{BS}^{3}$ cross-linking distinguishes surface and intracellular AMPARs}

$\mathrm{BS}^{3}$ selectively cross-links cell surface receptors, forming high molecular weight aggregates, whereas intracellular receptors are not modified. Thus, surface and intracellular receptor pools can be distinguished based on molecular weight using SDS-PAGE and Western blotting. Figure 1 shows control experiments that validate the use of the high molecular weight band as a measure of surface-expressed proteins and confirm that $\mathrm{BS}^{3}$ does not have access to intracellular antigens, as would be predicted from its chemical structure (Mattson et al., 1993). The first experiment used bilateral NAc tissue from naive rats. One NAc was crosslinked, whereas the other was treated identically but in the absence of $\mathrm{BS}^{3}$. Immunoblot analysis of GluR1 in cross-linked tissue revealed both high molecular weight and monomeric molecular weight bands, whereas only the monomeric molecular weight band was detected in noncross-linked tissue (Fig. $1 \mathrm{~A}$ ). In a separate experiment, it was determined that $\mathrm{BS}^{3}$ does not have access to intracellular proteins, based on selective immunodetection of the monomeric band but no cross-linked band for the intracellular protein tyrosine hydroxylase (Fig. 1B). Previous studies similarly found that $\mathrm{BS}^{3}$ does not cross-link other intracellular proteins (Hall and Soderling, 1997b). Additional experiments (data not shown) established that immunodetection of both $\mathrm{S}$ and $\mathrm{I}$ bands is proportional to total protein load over a log of loading concentrations (5-50 $\mu \mathrm{g})$, resulting in consistent S/I ratios over typical SDS-PAGE-loading concentrations.

\section{$\mathrm{BS}^{3}$ cross-linking measures in vivo GluR1 redistribution produced by a single cocaine injection}

We conducted a positive control experiment to verify that $\mathrm{BS}^{3}$ cross-linking can detect AMPAR redistribution produced by in vivo drug treatment. Ungless et al. (2001) compared excitatory transmission in midbrain slices from control mice and mice injected the day before with a single injection of cocaine, sufficient to produce "one-shot" behavioral sensitization. In slices from cocaine-treated mice, they observed an increase in the portion of the EPSC mediated by AMPARs relative to NMDA receptors (the AMPA/NMDA ratio). An increase in this ratio is diagnostic for LTP, reflecting insertion of new AMPARs into postsynaptic sites (Malinow and Malenka, 2002). The cocaine-induced increase in the AMPA/NMDA ratio was not accompanied by an increase in total GluR1 levels as determined by Western blotting (Ungless et al., 2001). Based on their work, we hypothesized that the $\mathrm{BS}^{3}$ assay should detect an increase in the GluR1 S/I ratio in the VTA of cocaine-treated rats. Rats were administered saline $(1 \mathrm{ml} / \mathrm{kg}$, i.p.; $n=9$ ) or cocaine (30 mg/kg, i.p.; $n=9)$, and 24 h later the VTA was rapidly dissected and cross-linked as described in Materials and Methods. Immunoblotting for GluR1 demonstrated a significant increase in the GluR1 S/I ratio in cocaine-treated rats compared with saline controls, in agreement with electrophysio-

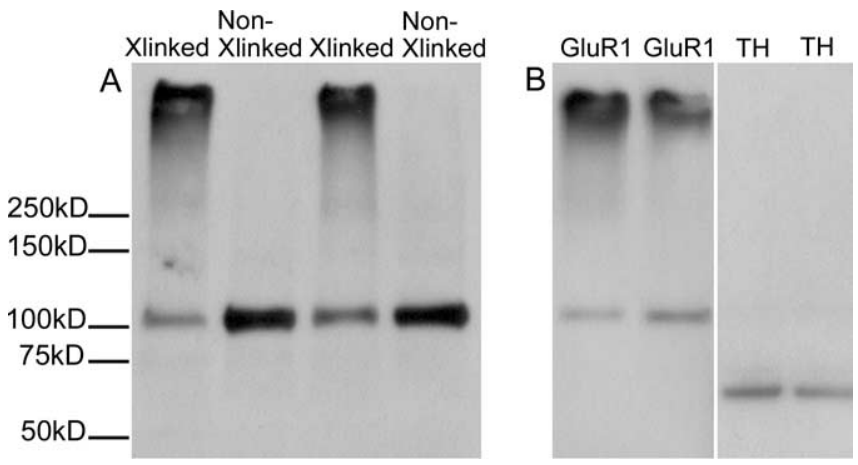

Figure 1. $\mathrm{BS}^{3}$ cross-linking measures surface and intracellular pools of GluR1. $\boldsymbol{A}$, The NAC was dissected from a naive rat. One side was cross-linked, whereas the other was not, generating paired samples that were then immunoblotted for GluR1. Both high (surface-expressed) and monomeric (intracellular) molecular weight bands are detected in tissue from the crosslinked side (Xlinked), whereas noncross-linked (Non-Xlinked) tissue yields the monomeric molecular weight band only. $\boldsymbol{B}$, In cross-linked NAc tissue, only proteins found both on the surface and inside the cell (GluR1, left) result in high and monomeric molecular weight bands. Proteins that are exclusively intracellular [tyrosine hydroxylase (TH); right] result in a monomeric molecular weight band only, confirming that the cross-linker does not cross cell membranes.

logical findings [saline, $100 \pm 33 \%(n=9)$; cocaine, $241 \pm 53 \%$ $(n=9)$; mean \pm SEM, normalized to saline group; ${ }^{\star} p<0.05$, Student's $t$ test]. Cocaine did not significantly alter total GluR1, quantified by summing the optical densities of surface and intracellular bands $(S+I)$ and normalizing to total protein in the lane [saline, $100 \pm 19(n=9)$; cocaine, $193 \pm 60(n=9) ; p=0.26$; Student's $t$ test]. However, there was a trend toward an increase in the cocaine group. Two previous Western blotting studies found that repeated cocaine injections increased GluR1 levels in total tissue homogenates of the VTA (Fitzgerald et al., 1996; Churchill et al., 1999), although no increase was detected using immunoautoradiography (Lu et al., 2002) or observed after cocaine selfadministration (Lu et al., 2003).

\section{Repeated cocaine injections produce behavioral sensitization in a subset of rats}

The main goal of this study was to characterize changes in AMPAR surface expression in the rat NAc associated with behavioral sensitization to cocaine. Sensitization was produced using a well characterized regimen (Pierce et al., 1996; Churchill et al., 1999). Cocaine-treated rats received $15 \mathrm{mg} / \mathrm{kg}$ cocaine in photobeam cages on day $1,30 \mathrm{mg} / \mathrm{kg}$ cocaine in home cages on days $2-6$, and $15 \mathrm{mg} / \mathrm{kg}$ cocaine in photobeam cages on day 7 . Control rats received saline injections on all days. Locomotor activity was measured on days 1 and 7. Because only a limited number of rats can be processed simultaneously, we performed four independent but identical behavioral trials. Rats from two of these trials were killed $1 \mathrm{~d}$ after the last injection (day 8) to study AMPAR distribution at a short withdrawal time (pooled behavioral data from these trials are shown in Fig. 2 A). Rats from the other two trials were killed $21 \mathrm{~d}$ after the last injection (pooled behavioral data are shown in Fig. 2 B). The magnitude of behavioral sensitization, assessed as the ratio of beam breaks on days 7 and 1, was similar for cocaine-treated groups in all trials. However, when data from individual rats were examined, it was apparent that only a subset of cocaine rats in each trial had developed behavioral sensitization. Applying criteria described in Materials and Methods, we divided cocaine-treated rats into sensitized and nonsensitized subgroups. Approximately $40 \%$ of all cocainetreated rats developed behavioral sensitization, similar to previ- 

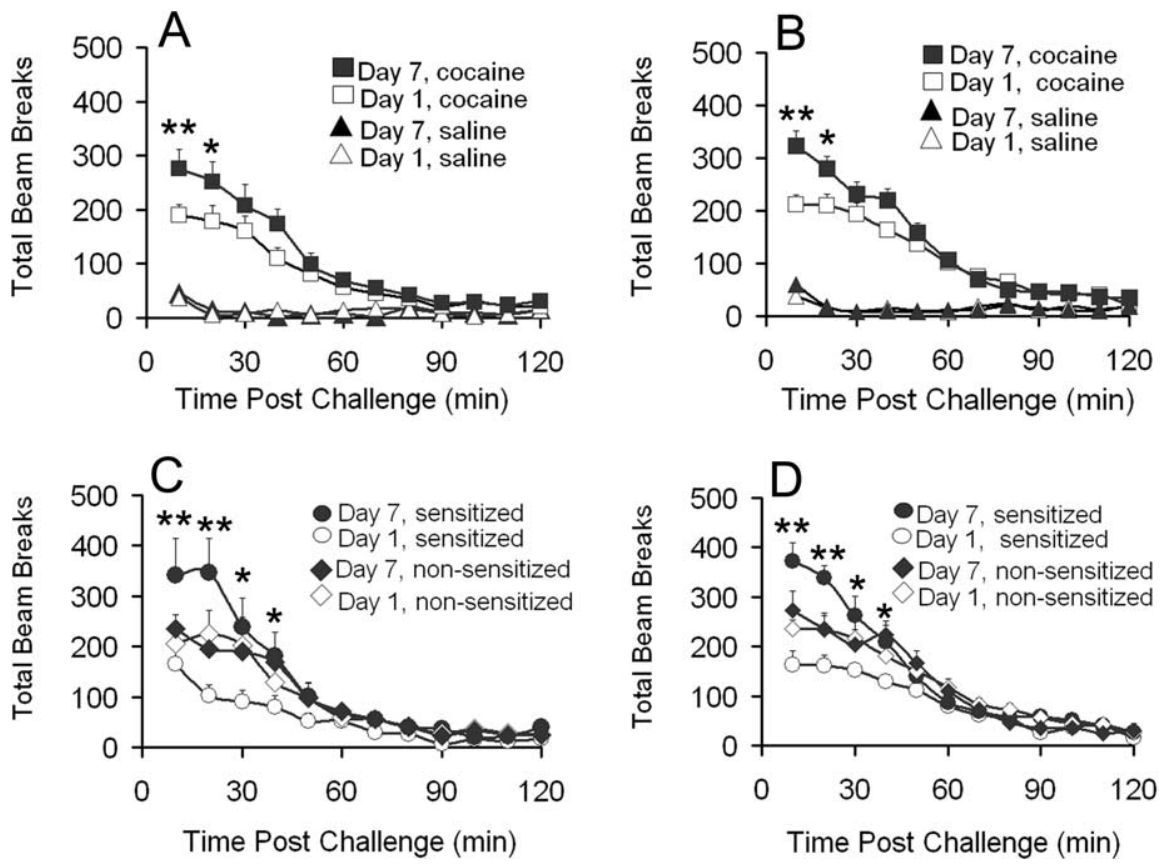

Figure 2. Repeated cocaine injections produce behavioral sensitization in a subset of rats. $A, B$, Locomotor activity data for all animals receiving repeated cocaine and saline injections; sum of two independent trials for both $\boldsymbol{A}$ and $\boldsymbol{B}$ (4 trials total). After behavioral testing was completed, rats from trials shown in $\boldsymbol{A}$ were killed for biochemical analysis $1 \mathrm{~d}$ after the last cocaine injection. Rats from trials shown in $\boldsymbol{B}$ were used for biochemical analysis $21 \mathrm{~d}$ after the last cocaine injection. $\boldsymbol{C}$, Cocaine-treated rats from $\boldsymbol{A}$ were divided into sensitized and nonsensitized subgroups (see Materials and Methods for criteria), and locomotor activity data were reanalyzed. $\boldsymbol{D}$, Cocaine-treated rats from $\boldsymbol{B}$ were divided into sensitized and nonsensitized subgroups, and locomotor activity data were reanalyzed. All data are expressed as mean \pm SEM total beam breaks. ${ }^{* *} p<0.01$; $p<0.05$ for comparison between beam breaks on day 1 versus day 7 .
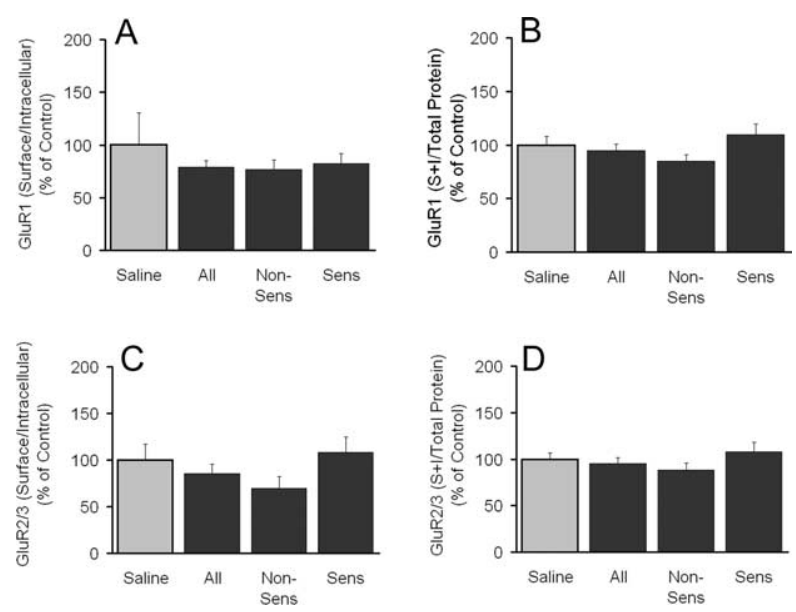

Figure 3. GluR1 and GluR2/3 surface to intracellular ratios and total protein levels are unchanged $1 \mathrm{~d}$ after the last cocaine injection. $\boldsymbol{A}$, GluR1 S/I ratio. $\boldsymbol{B}$, GluR1 total protein levels $(S+$ I, normalized to total protein in the lane). C, GluR2/3 S/I ratio. D, GluR2/3 total protein levels (S + I normalized to total protein in the lane). Data (mean \pm SEM) are normalized to saline controls and represent the sum of two independent experiments (see Fig. 2, $A$ and C, for corresponding behavioral trial data). Saline, $n=12$; all cocaine, $n=15$; nonsensitized (Non-Sens), $n=9$; sensitized (Sens), $n=6$.

ous reports using this regimen (Pierce et al., 1996; Churchill et al., 1999). Data from sensitized and nonsensitized cocaine-treated rats destined for the $1 \mathrm{~d}$ withdrawal group are shown in Figure $2 C$, whereas data from cocaine-treated rats in the $21 \mathrm{~d}$ withdrawal group are shown in Figure $2 D$. In both cases, sensitized rats displayed an increase in activity counts of approximately twofold (based on a comparison of the first $30 \mathrm{~min}$ of day 7 and day 1 tests), whereas nonsensitized rats had no appreciable change in response to cocaine. Changes in receptor distribution were then evaluated separately for sensitized and nonsensitized cocaine-treated rats.

\section{GluR1 and GluR2/3 distribution in the NAc is not altered $1 \mathrm{~d}$ after the last cocaine injection}

In rats killed $1 \mathrm{~d}$ after the last cocaine injection, the GluR1 S/I ratio was not significantly altered compared with saline controls, regardless of sensitization status (Fig. 3A). GluR1 total protein levels (S+I; normalized to total protein in the lane) were also unchanged (Fig. $3 B$ ). Spearman rank order (SRO) was used to determine whether there was any relationship between the magnitude of behavioral sensitization and the GluR1 S/I ratio for all cocaine-treated rats (sensitized plus nonsensitized). No significant correlations were found between the magnitude of behavioral sensitization (day 7/day 1 beam breaks) and the GluR1 S/I ratio (SRO, $-0.218 ; p=0.44)$. When aliquots of cross-linked NAc tissue from the same rats were immunoblotted for GluR2/3, results were similar to those obtained for GluR1. No significant differences in the GluR2/3 $\mathrm{S} / \mathrm{I}$ ratio or GluR2/3 total protein levels were found between any of the experimental groups (saline, all cocaine, nonsensitized, and sensitized) (Fig. 3C,D). Furthermore, no significant correlations existed between the GluR2/3 S/I ratio and the magnitude of behavioral sensitization (SRO, 0.310; $p=0.25$ ).

\section{GluR1 and GluR2/3 S/I ratios in the NAc are increased $21 \mathrm{~d}$ after the last cocaine injection and correlate with the magnitude of behavioral sensitization}

In rats killed $21 \mathrm{~d}$ after the last cocaine injection, the GluR1 S/I ratio was significantly increased $(p<0.005)$ in rats that developed behavioral sensitization compared with saline controls (Fig. $4 A)$. In addition, a significant difference $(p<0.001)$ between the GluR1 S/I ratio in behaviorally sensitized and nonsensitized rats was found. No significant differences in GluR1 total protein levels ( $\mathrm{S}+\mathrm{I}$; normalized to total protein in the lane) were observed between any of the groups tested (Fig. $4 B$ ). When we compared the magnitude of behavioral sensitization to the GluR1 S/I ratio for all rats that received cocaine, a highly significant positive relationship was discovered (SRO, 0.71; $p<0.001$ ) (Fig. 4C). Similarly, when GluR2/3 was studied in tissue aliquots from the same rats, a highly significant $(p<0.001)$ increase was found in the S/I ratio of cocaine-sensitized rats compared with saline controls (Fig. 4D). As observed for GluR1, a significant difference also existed between the GluR2/3 S/I ratios of cocaine-sensitized and -nonsensitized rats $(p<0.005)$. No differences were found in GluR2/3 total protein levels between any of the groups (Fig. $4 E$ ). There was a significant positive correlation between the GluR2/3 $S / I$ ratio and the magnitude of behavioral sensitization for all cocaine-treated rats (SRO, 0.57; $p<0.05$ ) (Fig. $4 F$ ). 

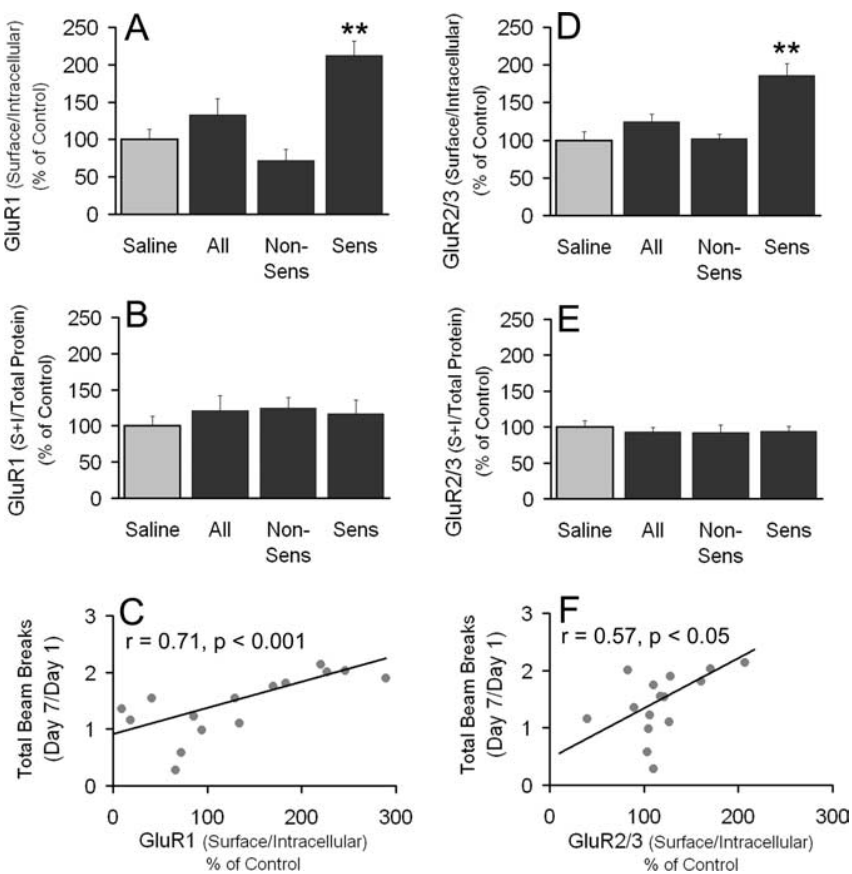

Figure 4. GluR1 and GluR2/3 surface to intracellular ratios $(S / I)$ are increased in cocainesensitized rats $21 \mathrm{~d}$ after the last injection, and the magnitude of $S / \mathrm{I}$ is positively correlated with the magnitude of sensitization. Data (mean \pm SEM) are normalized to saline controls and represent the sum of two independent trials (see Fig. $2, B$ and $D$, for corresponding behavioral trial data). $\boldsymbol{A}$, GluR1 S/I ratio ( ${ }^{* *} p<0.01$ relative to saline and nonsensitized groups). $\boldsymbol{B}$, GluR1 total protein levels ( $S+I$, normalized to total protein in the lane). Non-Sens, Nonsensitized; Sens, sensitized. C, Relationship between the magnitude of behavioral sensitization (day 7/day 1 beam breaks; first 30 min of activity after cocaine injection) and the GluR1 S/I ratio for all cocaine-treated rats. Data represent the sum of two independent trials; $r=$ Spearman rank order. $\boldsymbol{D}, \mathrm{GluR2} / 3 \mathrm{~S} / \mathrm{I}$ ratio ( ${ }^{* *} p<0.01$ relative to saline and nonsensitized groups). $\boldsymbol{E}, \mathrm{GluR2} / 3$ total protein levels ( $S+I$, normalized to total protein in the lane). Non-Sens, Nonsensitized; Sens, sensitized. $\boldsymbol{F}$, Relationship between the magnitude of behavioral sensitization (day 7/day 1 beam breaks; first 30 min of activity after cocaine injection) and the GluR2/3 S/I ratio for all cocaine-treated rats. Data represent the sum of two independent trials; $r=$ Spearman rank order. Saline, $n=18$; all cocaine, $n=16$; nonsensitized, $n=9$; sensitized, $n=7$.

\section{Cocaine produces proportional changes in GluR1 and GluR2/3 distribution}

AMPARs are heteromultimers, and most GluR1-containing receptors in the striatum and other forebrain regions also contain GluR2 or GluR3 (Wenthold et al., 1996; Bernard et al., 1997; Gold et al., 1997). This suggests that GluR1 and GluR2/3 subunits should redistribute proportionally. This was tested using SRO to evaluate the relationship between GluR1 S/I and GluR2/3 S/I ratios for individual rats. In cocaine-treated rats killed $1 \mathrm{~d}$ after the last injection, there was a trend toward a positive correlation (SRO, $0.41 ; p=0.2$ ) (Fig. $5 A$ ), whereas there was a statistically significant positive correlation for cocaine-treated rats analyzed $21 \mathrm{~d}$ after the last injection (SRO, 0.571; $p<0.05$ ) (Fig. 5B). In addition, saline control rats analyzed $1 \mathrm{~d}$ (Fig. $5 C$ ) or $21 \mathrm{~d}$ (Fig. $5 D$ ) after the last saline injection exhibited a significant positive correlation between GluR1 S/I and GluR2/3 S/I ratios (SRO, 0.857, $p<0.005$ and SRO, 0.593, $p<0.05,1$ and $21 \mathrm{~d}$, respectively). These results are consistent with the coexistence of GluR1 and GluR2/3 subunits in heteromultimeric AMPARs and further validate the $\mathrm{BS}^{3}$ cross-linking assay as a method for monitoring in vivo AMPAR trafficking.

\section{Surface-expressed GluR1 is associated with PSD-95}

Although significant correlations between behavioral and biochemical data from cocaine-treated rats at the $21 \mathrm{~d}$ withdrawal
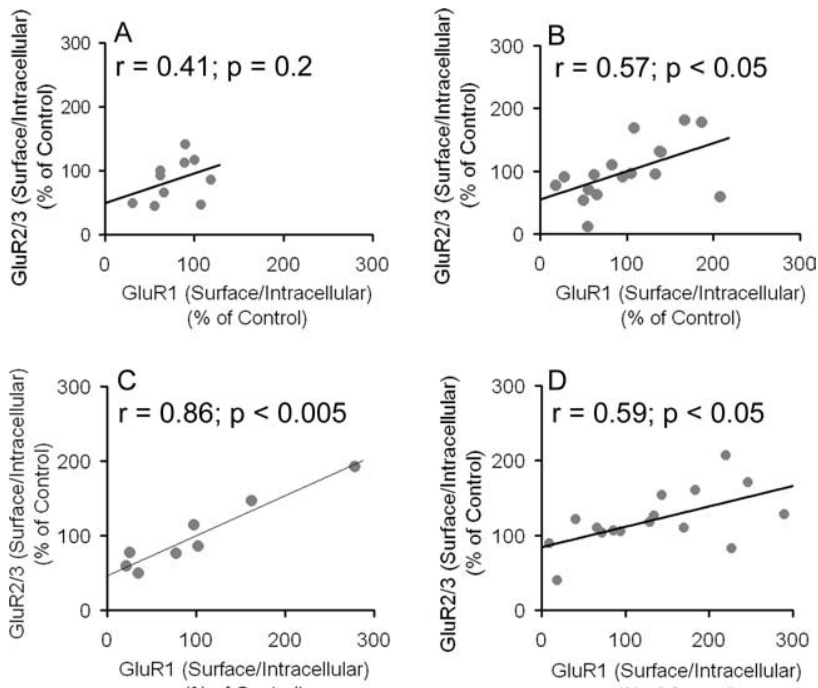

(\% of Control)

( $\%$ of Control)

Figure 5. Relationship between GluR1 and GluR2/3 surface to intracellular ratios ( $S / I)$ for all cocaine- and saline-treated rats. $A$, GluR1 $S / I$ ratio versus GluR2/3 S/I ratio $1 \mathrm{~d}$ after the last cocaine injection. $B$, GluR1 $S / I$ ratio versus $G l u R 2 / 3 S / I$ ratio $21 \mathrm{~d}$ after the last cocaine injection. C, GluR1 S/I ratio versus GluR2/3 S/I ratio $1 \mathrm{~d}$ after the last saline injection. D, GluR1 S/I ratio versus GluR2/3 S/I ratio $21 \mathrm{~d}$ after the last saline injection. $r=$ Spearman rank order. For some rats, S/I ratio data were only obtained for one subunit (GluR1 or GluR2/3), accounting for a lower sample number in some of these analyses compared with the behavioral trials.

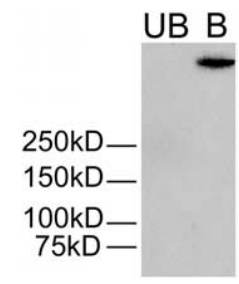

Figure 6. Immunodetection of GluR1 in NAc tissue obtained from a control rat after immunoprecipitation with an antibody to PSD-95. UB (Unbound), Portion of sample not associated with immunoprecipitating antibody; B (Bound), portion of sample associated with immunoprecipitating antibody.

time indicate that the $\mathrm{BS}^{3}$ cross-linking assay measures functionally significant pools of AMPARs, a limitation of these results is that we cannot distinguish between synaptic and extrasynaptic receptors. To address this issue, we used a coimmunoprecipitation approach, using PSD-95 as the precipitating protein. We hypothesized that if cell surface receptors detected in the crosslinked tissue are synaptic, cross-linked receptors should coimmunoprecipitate with PSD-95. We chose PSD-95 because it is enriched in the postsynaptic density, has physical associations with GluR1 (Vinade et al., 2003), and regulates synaptic targeting of GluR1 (Schnell et al., 2002; Ehrlich and Malinow, 2004). Results from the NAc of a representative control rat are shown in Figure 6. We observed 100\% coimmunoprecipitation of crosslinked (surface) GluR1 with PSD-95 as demonstrated by the immunodetection of GluR1 in the bound fraction but not in the unbound fraction. No GluR1 immunoreactivity was observed in the bound fraction when a mouse isotype control antibody was used as the precipitating antibody (data not shown). These results indicate that all GluR1 on the cell surface is associated with PSD-95 and is therefore likely to be synaptic, consistent with a report that most AMPARs in striatal dendrites are located near synapses (Bernard et al., 1997). However, it should be noted that cell surface AMPARs exchange rapidly between synaptic and ex- 
trasynaptic compartments (Triller and Choquet, 2005), and the role of PSD-95 in this process is not known.

\section{Discussion}

There is considerable evidence that activity-dependent plasticity contributes to behavioral sensitization (Kauer, 2004; Wolf et al., 2004), and AMPAR trafficking is critical for plasticity (see Introduction). Using cultured neurons, we established that dopamine (DA) receptors modulate AMPAR trafficking (Chao et al., 2002; Mangiavacchi and Wolf, 2004; Sun et al., 2005), suggesting a way for DA-releasing psychomotor stimulants to influence plasticity. In the present study, we focused on AMPAR transmission in the NAc because of its key role in behavioral sensitization and drugseeking behavior. After $21 \mathrm{~d}$ of withdrawal, GluR1 and GluR2/3 $\mathrm{S} / \mathrm{I}$ ratios were significantly increased in cocaine-sensitized rats compared with saline controls and rats that failed to sensitize, and S/I ratios were positively correlated with the magnitude of behavioral sensitization. At the $1 \mathrm{~d}$ withdrawal time, cocaine did not alter S/I ratios, and there was no correlation between S/I ratios and sensitization. These findings indicate an important role for increased AMPAR surface expression in the NAc in cocaine sensitization at long withdrawal times. A relationship between AMPARs and sensitization after long but not short withdrawals is also supported by experiments measuring AMPAR levels (below) and reports that AMPAR antagonists block expression of cocaine sensitization only at long withdrawal times (Pierce et al., 1996; Li et al., 1997).

The effect of cocaine on AMPAR expression in the NAc has been studied previously. After the same cocaine regimen used herein, total tissue levels of GluR1 increased in sensitized rats after $21 \mathrm{~d}$ but not $1 \mathrm{~d}$ of withdrawal, whereas GluR2/3 was unchanged (Churchill et al., 1999). GluR1 and GluR2 mRNA levels were unchanged after $21 \mathrm{~d}$ of withdrawal, whereas GluR3 mRNA decreased (Ghasemzadeh et al., 1999). Studies using different sensitization regimens found increased GluR1 after long withdrawals (Scheggi et al., 2002) but not short withdrawals (Fitzgerald et al., 1996). Increased AMPAR subunit levels have also been reported after cocaine self-administration (Lu et al., 2003; Tang et al., 2004). Comparison with our results is difficult because the $\mathrm{BS}^{3}$ assay distinguishes between surface and intracellular receptors, whereas traditional Western analysis measures receptor protein regardless of location.

\section{Significance of increased AMPAR surface expression for drug-seeking behavior}

The output of NAc neurons is critical for the expression of addiction-related behaviors such as sensitization and reinstatement (Kalivas and McFarland, 2003). Our findings suggest that behavioral sensitization to cocaine is associated with a slowly developing redistribution of AMPARs to the surface of NAc neurons. This provides a mechanism to account for augmentation of the locomotor response to intra-NAc injection of AMPA in cocaine-sensitized rats in experiments using the same cocaine regimen and withdrawal time (Pierce et al., 1996). We further propose that increased surface expression of AMPARs is important for increasing vulnerability to reinstatement of drug-seeking behavior. This is consistent with the demonstration that preexposure to amphetamine or cocaine enhances the ability of intra-NAc AMPA to reinstate drug-seeking behavior (Suto et al., 2004). This enhancement in responsiveness to AMPA followed a time course similar to the increased S/I ratio for AMPAR subunits; enhanced reinstatement was observed several weeks but not $4 \mathrm{~d}$ after discontinuing drug exposure (Suto et al., 2004), whereas increased AMPAR surface expression was observed $21 \mathrm{~d}$ but not $1 \mathrm{~d}$ after discontinuing cocaine. Under physiological conditions, cocaine-seeking behavior is elicited not by intra-NAc injection of AMPA but rather by stress, a priming injection of cocaine, or cocaine-conditioned cues. However, all of these stimuli are believed to trigger drug seeking at least in part by activating limbic and cortical glutamate projections that terminate in the NAc (Kalivas and McFarland, 2003). This may occur more effectively in cocaine-sensitized rats because of increased surface expression of AMPARs on NAc neurons. This hypothesis requires that increased AMPAR surface expression occur at synapses. In fact, our coimmunoprecipitation results suggest that all surfaceexpressed GluR1 detected by $\mathrm{BS}^{3}$ cross-linking is associated with the synaptic protein PSD-95.

Although behavioral studies in intact rats have found increased sensitivity to AMPA in the NAc of cocaine-sensitized rats (Pierce et al., 1996; Suto et al., 2004), results of electrophysiological studies have been mixed. Yao et al. (2004) found enhanced LTP at corticoaccumbal glutamate synapses in slices prepared from mice 2-3 d after the last cocaine injection. In contrast, Thomas et al. (2001) reported LTD in NAc slices from cocainesensitized mice withdrawn for 10-14 d. However, LTD was observed only at a subset of synapses in the NAc shell and was not observed in the core (the core accounts for the majority of tissue in our dissection; see Materials and Methods). Furthermore, mice received a challenge injection of cocaine on the day before recording, which could have altered glutamate receptor distribution. White et al. (1995) observed subsensitivity to iontophoretic glutamate in NAc neurons recorded from anesthetized rats $3 \mathrm{~d}$ after discontinuing repeated cocaine or amphetamine injections, but this may reflect decreased calcium currents in NAc neurons at this withdrawal time (Zhang et al., 2002; Hu et al., 2004). Another consideration is that different techniques sample AMPARs on different portions of the cell. For example, increased surface expression of AMPARs on distal dendrites might be detected by the $\mathrm{BS}^{3}$ assay but not by iontophoresis, which delivers glutamate close to the somatic recording site.

\section{Possible mechanisms underlying increased AMPAR surface expression}

Using cultured NAc and prefrontal cortex neurons, we showed that activation of the $\mathrm{D}_{1}$ receptor-protein kinase $A$ (PKA) signaling pathway increases the rate of externalization of GluR1containing AMPARs (Chao et al., 2002; Mangiavacchi and Wolf, 2004; Sun et al., 2005). Increases in both PKA activity (Lu et al., 2003) and $D_{1}$ receptor signaling (Henry and White, 1995) have been reported in the NAc during the first month after discontinuing repeated cocaine treatment. Our results in cultured neurons suggest that either effect could account for increased AMPAR surface expression. However, it could also reflect activation of other cascades involved in AMPAR synaptic insertion such as ERK (extracellular signal-regulated kinase) (Zhu et al., 2002) or calcium calmodulin-dependent protein kinase II (CaMKII) (Hayashi et al., 2000). CaMKII signaling in the NAc is required for expression of cocaine sensitization (Pierce et al., 1998).

Another possibility is that increased AMPAR surface expression is a response to altered excitatory transmission. During the homeostatic process of synaptic scaling, long-term decreases in excitatory synaptic transmission trigger upregulation of synaptic AMPARs, whereas increased activity produces the opposite effect (Turrigiano and Nelson, 2004). The cocaine regimen used herein has been reported to decrease basal extracellular glutamate levels in the NAc by $\sim 50 \%$ (Pierce et al., 1996; Baker et al., 2003). 
However, a decrease in extracellular glutamate levels does not necessarily imply a decrease in synaptic glutamate, so scaling might not occur. Furthermore, glutamate levels are decreased in nonsensitized as well as sensitized rats (Pierce et al., 1996), whereas AMPAR S/I ratios increase only in sensitized rats. Another consideration is that repeated cocaine decreases glutamate levels in the NAc core but not the shell (Pierce et al., 1996). Our dissection contains more core than shell, but future studies will be necessary to determine whether AMPAR surface expression is increased selectively within one of these regions. Previous studies have established strong correlations between addiction-related behaviors and transmission or plasticity at glutamate synapses in the core (Kalivas and McFarland, 2003; Li et al., 2004).

\section{Methodological considerations}

Our results demonstrate that the adapted $\mathrm{BS}^{3}$ assay can measure receptor redistribution after in vivo treatments. The assay can be applied to any animal model. Once tissue from treated rats is cross-linked and frozen, it represents a tissue bank that can be used to analyze multiple receptors or signaling molecules in the same rats and then evaluate possible correlations. Importantly, the assay enables analysis of receptor trafficking in adult tissue. Most trafficking research has used tissue from young animals, which is problematic if plasticity mechanisms change during development (Zhu et al., 2000; Grosshans et al., 2002b). A limitation is that the $\mathrm{BS}^{3}$ assay does not distinguish between synaptic and extrasynaptic receptors, although we show that it can be combined with coimmunoprecipitation to evaluate the extent to which a surface-expressed protein is associated with synaptic markers.

Alternative methods exist for monitoring receptor surface expression. Some are similar to the $\mathrm{BS}^{3}$ assay in that they rely on selective modification of surface-expressed receptors, but the $\mathrm{BS}^{3}$ assay is more efficient and accurate (see Materials and Methods). Another approach is to conduct a manipulation in the rat and then monitor receptor levels in synaptoneurosomes (Quinlan et al., 1999) or synaptosomes (Du et al., 2004). However, redistribution of receptors to these fractions does not necessarily mean they are expressed in the synapse or even on the surface. Electrophysiological approaches are very powerful for monitoring synaptic targeting of receptors, but a biochemical approach is more efficient for comparing experimental groups.

\section{Conclusions}

We developed a protein cross-linking assay that provides, for the first time, direct evidence that glutamate receptor trafficking contributes to cocaine-induced behavioral adaptations. Using this assay, we have shown that AMPAR surface expression is increased in the NAc of cocaine-sensitized rats. Motor execution of drug-seeking responses depends on activation of AMPARs on NAc neurons by glutamate afferents originating in cortical and limbic regions. We propose that drug-seeking responses are more effectively triggered in cocaine-sensitized rats because of increased cell surface expression of AMPARs.

\section{References}

Archibald K, Perry MJ, Molnar E, Henley JM (1998) Surface expression and metabolic half-life of AMPA receptors in cultured rat cerebellar granule cells. Neuropharmacology 37:1345-1353.

Baker DA, McFarland K, Lake RW, Shen H, Tang XC, Toda S, Kalivas PW (2003) Neuroadaptations in cystine-glutamate exchange underlie cocaine relapse. Nat Neurosci 6:743-749.

Bernard V, Somogyi P, Bolam JP (1997) Cellular, subcellular, and subsyn- aptic distribution of AMPA-type glutamate receptor subunits in the neostriatum of the rat. J Neurosci 17:819-833.

Bredt DS, Nicoll RA (2003) AMPA receptor trafficking at excitatory synapses. Neuron 40:361-379.

Broutman G, Baudry M (2001) Involvement of the secretory pathway for AMPA receptors in NMDA-induced potentiation in hippocampus. J Neurosci 21:27-34.

Chao SZ, Ariano MA, Peterson DA, Wolf ME (2002) $D_{1}$ dopamine receptor stimulation increases GluR1 surface expression in nucleus accumbens neurons. J Neurochem 83:704-712.

Churchill L, Swanson CJ, Urbina M, Kalivas PW (1999) Repeated cocaine alters glutamate receptor subunit levels in the nucleus accumbens and ventral tegmental area of rats that develop behavioral sensitization. J Neurochem 72:2397-2403.

Clayton DA, Grosshans DR, Browning MD (2002) Aging and surface expression of hippocampal NMDA receptors. J Biol Chem 277:14367-14369.

Cornish JL, Kalivas PW (2000) Glutamate transmission in the nucleus accumbens mediates relapse in cocaine addiction. J Neurosci 20:89RC(1-5).

Du J, Gray NA, Falke CA, Chen W, Yuan P, Szabo ST, Einat H, Manji HK (2004) Modulation of synaptic plasticity by antimanic agents: the role of AMPA glutamate receptor subunit 1 synaptic expression. J Neurosci 24:6578-6589.

Ehrlich I, Malinow R (2004) Postsynaptic density 95 controls AMPA receptor incorporation during long-term potentiation and experience-driven synaptic plasticity. J Neurosci 24:916-927.

Fitzgerald LW, Ortiz J, Hamedani AG, Nestler EJ (1996) Drugs of abuse and stress increase the expression of GluR1 and NMDAR1 glutamate receptor subunits in the rat ventral tegmental area: common adaptations among cross-sensitizing agents. J Neurosci 16:274-282.

Gerges NZ, Tran IC, Backos DS, Harrell JM, Chinkers M, Pratt WB, Esteban JA (2004) Independent functions of hsp90 in neurotransmitter release and in the continuous synaptic cycling of AMPA receptors. J Neurosci 24:4758-4766.

Ghasemzadeh MB, Nelson LC, Lu XY, Kalivas PW (1999) Neuroadaptations in ionotropic and metabotropic glutamate receptor mRNA produced by cocaine treatment. J Neurochem 72:157-165.

Gold SJ, Ambros-Ingerson J, Horowitz JR, Lynch G, Gall CM (1997) Stoichiometries of AMPA receptor subunit mRNAs in rat brain fall into discrete categories. J Comp Neurol 385:491-502.

Grosshans DR, Clayton DA, Coultrap SJ, Browning MD (2002a) Analysis of glutamate receptor surface expression in acute hippocampal slices. Sci STKE http://stke.sciencemag.org/cgi/content/full/sigtrans;2002/137/p18.

Grosshans DR, Clayton DA, Coultrap SJ, Browning MD (2002b) LTP leads to rapid surface expression of NMDA but not AMPA receptors in adult rat CA1. Nat Neurosci 5:27-33.

Gutlerner JL, Penick EC, Snyder EM, Kauer JA (2002) Novel protein kinase A-dependent long-term depression of excitatory synapses. Neuron 36:921-931.

Hall RA, Soderling TR (1997a) Differential surface expression and phosphorylation of the $N$-methyl-D-aspartate receptor subunits NR1 and NR2 in cultured hippocampal neurons. J Biol Chem 272:4135-4140.

Hall RA, Soderling TR (1997b) Quantitation of AMPA receptor surface expression in cultured hippocampal neurons. Neuroscience 78:361-371.

Hall RA, Hansen A, Andersen PH, Soderling TR (1997) Surface expression of the AMPA receptor subunits GluR1, GluR2, and GluR4 in stably transfected baby hamster kidney cells. J Neurochem 68:625-630.

Hayashi Y, Shi S-H, Esteban JA, Piccini A, Poncer J-C, Malinow R (2000) Driving AMPA receptors into synapses by LTP and CaMKII: requirement for GluR1 and PDZ domain interaction. Science 287:2262-2267.

Henry DJ, White FJ (1995) The persistence of behavioral sensitization to cocaine parallels enhanced inhibition of nucleus accumbens neurons. J Neurosci 15:6287-6299.

Heynen AJ, Yoon BJ, Liu CH, Chung HJ, Huganir RL, Bear MF (2003) Molecular mechanism for loss of visual cortical responsiveness following brief monocular deprivation. Nat Neurosci 6:854-862.

Hu XT, Basu S, White FJ (2004) Repeated cocaine administration suppresses HVA-Ca ${ }^{2+}$ potentials and enhances activity of $\mathrm{K}^{+}$channels in rat nucleus accumbens neurons. J Neurophysiol 92:1597-1607.

Hunter C, Wheaton KC, Wenthold RJ (1990) Solubilization and partial purification of alpha-amino-3-hydroxy-5-methyl-4-isoxazolepropionic acid binding sites from rat brain. J Neurochem 54:118-125. 
Kalivas PW, McFarland K (2003) Brain circuitry and the reinstatement of cocaine-seeking behavior. Psychopharmacology 168:44-56.

Kauer JA (2004) Learning mechanisms in addiction: synaptic plasticity in the ventral tegmental area as a result of exposure to drugs of abuse. Annu Rev Physiol 66:447-475.

Kelley AE (2004) Ventral striatal control of appetitive motivation: role in ingestive behavior and reward-related learning. Neurosci Biobehav Rev 27:765-776.

Li Y, Vartanian AJ, White FJ, Xue CJ, Wolf ME (1997) Effects of the AMPA receptor antagonist NBQX on the development and expression of behavioral sensitization to cocaine and amphetamine. Psychopharmacology 134:266-276.

Li Y, Acerbo MJ, Robinson TE (2004) The induction of behavioral sensitization is associated with cocaine-induced structural plasticity in the core (but not shell) of the nucleus accumbens. Eur J Neurosci 20:1647-1654.

Lowry OH, Rosebrough NJ, Farr AL, Randall RJ (1951) Protein measurement with the folin phenol reagent. J Biol Chem 193:265-275.

Lu L, Grimm JW, Shaham Y, Hope BT (2003) Molecular neuroadaptations in the accumbens and ventral tegmental area during the first 90 days of forced abstinence from cocaine self-administration in rats. J Neurochem 85:1604-1613.

Lu W, Monteggia LM, Wolf ME (2002) Repeated administration of amphetamine or cocaine does not alter AMPA receptor subunit expression in the rat midbrain. Neuropsychopharmacology 26:1-13.

Malinow R, Malenka RC (2002) AMPA receptor trafficking and synaptic plasticity. Annu Rev Neurosci 25:103-126.

Mangiavacchi S, Wolf ME (2004) $D_{1}$ dopamine receptor stimulation increases the rate of AMPA receptor insertion onto the surface of cultured nucleus accumbens neurons through a pathway dependent on protein kinase A. J Neurochem 88:1261-1271.

Mattson G, Conklin E, Desai S, Neilander G, Savage MD, Morgensen S (1993) A practical approach to cross-linking. Mol Biol Rep 17:167-183.

Pierce RC, Bell K, Duffy P, Kalivas PW (1996) Repeated cocaine augments excitatory amino acid transmission in the nucleus accumbens only in rats having developed behavioral sensitization. J Neurosci 16:1550-1560.

Pierce RC, Quick EA, Reeder DC, Morgan ZR, Kalivas PW (1998) Calciummediated second messengers modulate the expression of behavioral sensitization to cocaine. J Pharmacol Exp Ther 286:1171-1176.

Quinlan EM, Philpot BD, Huganir RL, Bear MF (1999) Rapid, experiencedependent expression of synaptic NMDA receptors in visual cortex in vivo. Nat Neurosci 2:352-357.

Robinson TE, Berridge KC (2000) The psychology and neurobiology of addiction: an incentive-sensitization view. Addiction 95:S91-S117.

Scheggi S, Mangiavacchi S, Masi F, Gambarana C, Tagliamonte A, De Montis MG (2002) Dizocilpine infusion has a different effect in the development of morphine and cocaine sensitization: behavioral and neurochemical aspects. Neuroscience 109:267-274.

Schnell E, Sizemore M, Karimzadegan S, Chen L, Bredt DS, Nicoll RA (2002) Direct interactions between PSD-95 and stargazin control synaptic AMPA receptor number. Proc Natl Acad Sci USA 99:13902-13907.
Sun X, Zhao Y, Wolf ME (2005) Dopamine receptor stimulation modulates AMPA receptor synaptic insertion in prefrontal cortex neurons. J Neurosci 25:7342-7351.

Suto N, Tanabe LM, Austin JD, Creekmore E, Pham CT, Vezina P (2004) Previous exposure to psychostimulants enhances the reinstatement of cocaine seeking by nucleus accumbens AMPA. Neuropsychopharmacology 29:2149-2159.

Tang W, Wesley M, Freeman WM, Liang B, Hemby SE (2004) Alterations in ionotropic glutamate receptor subunits during binge cocaine selfadministration and withdrawal in rats. J Neurochem 89:1021-1033.

Thomas MJ, Beurrier C, Bonci A, Malenka RC (2001) Long-term depression in the nucleus accumbens: a neural correlate of behavioral sensitization to cocaine. Nat Neurosci 4:1217-1223.

Triller A, Choquet D (2005) Surface trafficking of receptors between synaptic and extrasynaptic membranes: and yet they do move! Trends Neurosci 28:133-139.

Turrigiano GG, Nelson SB (2004) Homeostatic plasticity in the developing nervous system. Nat Rev Neurosci 5:97-107.

Ungless MA, Whistler JL, Malenka RC, Bonci A (2001) Single cocaine exposure in vivo induces long-term potentiation in dopamine neurons. Nature 411:583-587.

Vanderschuren LJ, Kalivas PW (2000) Alterations in dopaminergic and glutamatergic transmission in the induction and expression of behavioral sensitization: a critical review of preclinical studies. Psychopharmacology (Berl) 151:99-120.

Vinade L, Chang M, Schlief ML, Petersen JD, Reese TS, Tao-Cheng JH, Dosemeci A (2003) Affinity purification of PSD-95-containing postsynaptic complexes. J Neurochem 87:1255-1261.

Wenthold RJ, Petralia RS, Blahos J, Niedzielski AS (1996) Evidence for multiple AMPA receptor complexes in hippocampal CA1/CA2 neurons. J Neurosci 16:1982-1989.

White FJ, Hu XT, Zhang XF, Wolf ME (1995) Repeated administration of cocaine or amphetamine alters neuronal responses to glutamate in the mesoaccumbens dopamine system. J Pharmacol Exp Ther 273:445-454.

Wolf ME (2003) Effects of psychomotor stimulants on glutamate receptor expression. Methods Mol Med 79:31.

Wolf ME, Sun X, Mangiavacchi S, Chao SZ (2004) Psychomotor stimulants and neuronal plasticity. Neuropharmacology 47 [Suppl 1]:61-79.

Yao WD, Gainetdinov RR, Arbuckle MI, Sotnikova TD, Cyr M, Beaulieu JM, Torres GE, Grant SGN, Caron MG (2004) Identification of PSD-95 as a regulator of dopamine-mediated synaptic and behavioral plasticity. Neuron 41:625-638.

Zhang XF, Cooper DC, White FJ (2002) Repeated cocaine treatment decreases whole-cell calcium current in rat nucleus accumbens neurons. J Pharmacol Exp Ther 301:1119-1125.

Zhu JJ, Esteban JA, Hayashi Y, Malinow R (2000) Postnatal synaptic potentiation: delivery of GluR4-containing AMPA receptors by spontaneous activity. Nat Neurosci 3:1098-1106.

Zhu JJ, Qin Y, Zhao M, van Aiest L, Malinow R (2002) Ras and Rap control AMPA receptor trafficking during synaptic plasticity. Cell 110:443-455. 